\title{
Zooshikella ganghwensis gen. nov., sp. nov., isolated from tidal flat sediments
}

\author{
Hana Yi, ${ }^{1}$ Young-Hyo Chang, ${ }^{2}$ Hyun Woo Oh, ${ }^{2}$ Kyung Sook Bae ${ }^{2}$ \\ and Jongsik Chun ${ }^{1}$ \\ ${ }^{1}$ School of Biological Sciences, Seoul National University, 56-1 Shillim-dong, Kwanak-gu, Seoul \\ 151-742, Republic of Korea \\ ${ }^{2}$ Korean Collection for Type Cultures, Korea Research Institute of Bioscience and \\ Biotechnology, Yusung PO Box 115, Taejon 305-600, Republic of Korea
}

\begin{abstract}
Two red pigment-producing bacterial strains with a metallic green sheen were isolated from a sediment sample of getbol, the Korean tidal flat. Phylogenetic analysis based on 16S rDNA sequences showed that these isolates represent a phyletic lineage within the $\gamma$-Proteobacteria that is distantly related to the genus Hahella. No bacterial species with validly published names showed $\geqslant 92 \% 16 \mathrm{~S}$ rRNA similarity with the getbol isolates. The strains were Gram-negative, chemo-organotrophic, aerobic and required $\mathrm{NaCl}(1-7 \%)$ for growth. They produced pigments with maximum absorption at $540 \mathrm{~nm}$, which indicated the presence of prodigiosin, a well-known red pigment previously detected in Serratia marcescens. The major isoprenoid quinone was ubiquinone-9. The predominant cellular fatty acids were saturated and monounsaturated straight-chain fatty acids. The DNA G + C contents ranged from 40 to $42 \mathrm{~mol} \%$. The combination of physiological, biochemical and chemotaxonomic data clearly separated the test strains from other phylogenetically related genera in the $\gamma$-Proteobacteria. On the basis of polyphasic evidence from this study, it is proposed that the two getbol isolates should be classified in a novel genus, Zooshikella gen. nov., as Zooshikella ganghwensis sp. nov.
\end{abstract}

The Korean tidal flat, called getbol, is the neutral zone that connects land and sea; it is largely found along the west coast of the Korean peninsula. It has been well-known for its vital biological functions, such as bioremediation of pollutants, fishery products, flood control, spawning and nursery grounds for marine animals, which may result from microbial activities and diversity (Korea Ocean Research \& Development Institute, 1998). However, members of microbial communities in getbol are largely unknown, as they have never been the subject of systematic taxonomic investigation. Recently, we have initiated a study that involves the isolation and identification of members of the aerobic bacterial community from getbol. In this study, we present the taxonomic properties of two isolates, for which the name Zooshikella ganghwensis sp. nov. is proposed.

\section{Isolation}

Two aerobic, halophilic bacterial strains were isolated from a sediment sample collected from the getbol of Ganghwa

Published online ahead of print on 29 November 2002 as DOI 10.1099/ijs.0.02521-0.

The GenBank accession numbers for the 165 rDNA sequences of strains JC2044 ${ }^{\top}$ and JC2045 are AY130994 and AY130995, respectively.
Island in Korea $\left(37^{\circ} 35^{\prime} 31 \cdot 9^{\prime \prime} \mathrm{N}, 126^{\circ} 27^{\prime} 24 \cdot 5^{\prime \prime} \mathrm{E}\right)$. The sample was diluted with sterilized artificial sea water (ASW; Lyman \& Fleming, 1940), spread onto a plate containing marine agar 2216 (MA; Difco) and incubated at $25^{\circ} \mathrm{C}$ for 3 weeks. The isolates were routinely cultured on MA and maintained as glycerol suspensions $\left(20 \%\right.$, w/v) at $-80{ }^{\circ} \mathrm{C}$.

\section{Molecular systematics}

$16 S$ rDNA was enzymically amplified from a single colony. Primers, PCR conditions and sequencing were performed as described elsewhere (Chun \& Goodfellow, 1995). The $16 \mathrm{~S}$ rDNA sequences of strains JC2044 ${ }^{\mathrm{T}}$ and JC2045 were manually aligned with representative sequences of the $\gamma$-Proteobacteria obtained from GenBank. Phylogenetic trees were inferred by using the Fitch-Margoliash (Fitch \& Margoliash, 1967), maximum-likelihood (Felsenstein, 1993), maximum-parsimony (Fitch, 1972) and neighbourjoining (Saitou \& Nei, 1987) methods. Evolutionary distance matrices for the neighbour-joining and FitchMargoliash methods were generated according to the model of Jukes \& Cantor (1969). The resultant neighbourjoining tree topology was evaluated by bootstrap analyses (Felsenstein, 1985) based on 1000 resamplings. The alignment and phylogenetic analyses were carried out using the PHYDIT (available at http://plaza.snu.ac.kr/ jchun/phydit/) 
and PAUP 4.0 (Swofford, 1998) programs, as described previously (Chun et al., 2000).

Nearly complete $16 \mathrm{~S}$ rDNA sequences of strains JC2044 ${ }^{\mathrm{T}}$ and JC2045 were obtained (1441 and $1448 \mathrm{bp}$, respectively). Preliminary sequence comparison against $16 \mathrm{~S}$ rDNA sequences in GenBank indicated that our isolates belonged to the $\gamma$-Proteobacteria. On the basis of $16 \mathrm{~S}$ rDNA similarity, our isolates showed no apparent relationship with other bacteria: no validly published bacterial species showed $92 \%$ or higher $16 \mathrm{~S}$ rRNA sequence similarity with the test strains. However, the sequence of an uncultured marine bacterium (GenBank no. AJ315452) showed $99 \%$ 16S rDNA similarity with our isolates. It is noteworthy that this sequence was derived from a sample of sea water from Dayawan Bay near Hong Kong. The result may indicate that taxa related to our isolates may be widespread in the marine environment that stretches from the Yellow Sea to the South China Sea.

The closest cultured bacterial relatives were Marinobacter aquaeolei DSM $11845^{\mathrm{T}}(91 \%)$, Marinobacter hydrocarbonoclasticus ATCC 27132 (91\%), Microbulbifer hydrolyticus DSM $11525^{\mathrm{T}}(91 \%)$, Hahella chejuensis KCTC $2396^{\mathrm{T}}$ (90\%), Oceanospirillum multiglobuliferum NBRC $13614^{\mathrm{T}}$ (89\%) and Oceanospirillum linum ATCC $11336^{\mathrm{T}}$ (89\%). This distant relationship between our isolates and cultured bacteria was also evident in the phylogenetic tree, where the two test strains, together with the sequence of an uncultured marine bacterium (GenBank number AJ315452), formed a monophyletic clade with a bootstrap value of $100 \%$ that was supported by all tree-making methods employed in this study (Fig. 1). Hahella chejuensis KCTC $2396^{\mathrm{T}}$ was recovered as a sister taxon to the clade that contained our isolates, although the relationship was not found in the maximum-likelihood and parsimony analyses. It is evident from phylogenetic analysis that our isolates represent a novel phyletic lineage in the $\gamma$-Proteobacteria.

The 16S rDNA similarity value between strains JC2044 ${ }^{\mathrm{T}}$ and JC2045 was $99 \cdot 7 \%$, corresponding to four nucleotide differences. Genomic relatedness between these isolates was examined further by using slot-blot DNA-DNA hybridization (Chun et al., 1998). The two isolates shared a high DNA-DNA relatedness value of $93 \%$, which is above the $70 \%$ threshold for delineating bacterial species (Wayne et al., 1987). It is clear from this DNA-DNA pairing study that the strains belong to the same genomic species.

\section{Morphology and physiological properties}

Cellular morphologies were examined after growth on MA at $30^{\circ} \mathrm{C}$ for 2 days by scanning and transmission electron microscopy. The motility of young cells was determined by phase-contrast microscopy. Cells were Gram-negative, slightly curved rods, $0 \cdot 7-0 \cdot 9 \mu \mathrm{m}$ in width and $1 \cdot 5-2 \cdot 5 \mu \mathrm{m}$ in length and actively motile with a single polar flagellum (Fig. 2). Spore formation was not observed under any of the growth conditions described in this study. The colonies

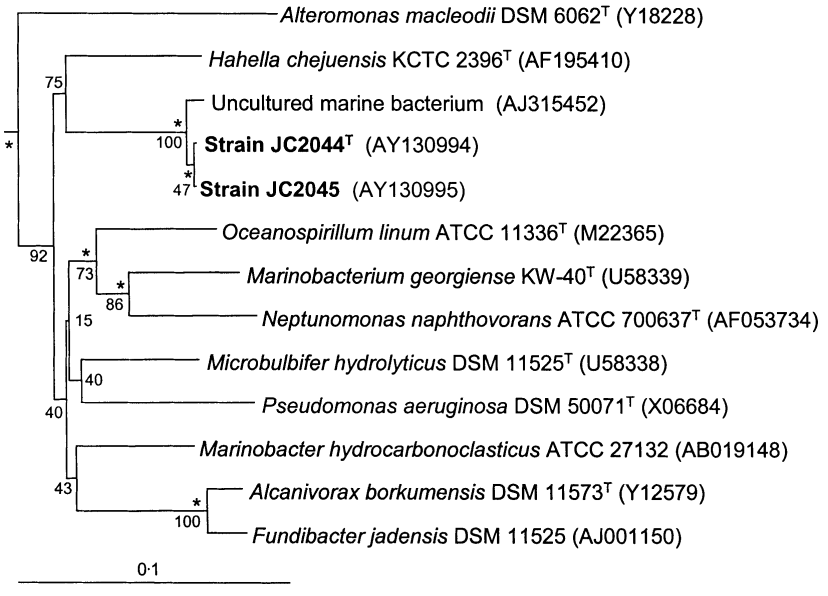

Fig. 1. Neighbour-joining tree based on nearly complete $16 \mathrm{~S}$ rDNA sequences, showing relationships between strains $\mathrm{JC} 2044^{\top}$ and JC2045 and members of the $\gamma$-Proteobacteria. Numbers at the nodes are levels of bootstrap support (\%), based on neighbour-joining analyses of 1000 resampled datasets. Asterisks indicate that the corresponding nodes (groupings) are also recovered in Fitch-Margoliash, maximumlikelihood and maximum-parsimony trees. Helicobacter pylori ATCC $43504^{\top}$ (U01330) was used as an outgroup. Bar, $0 \cdot 1$ nucleotide substitutions per position.

were circular, convex, entire, glistening, opaque and viscid on agar plates. When grown on MA at $30^{\circ} \mathrm{C}$, they were approximately $1 \mathrm{~mm}$ in diameter after $36 \mathrm{~h}$ and $1-2 \mathrm{~mm}$ after 3 days, and reached their maximum diameter of 4-5 mm after 1 week. The test strains produced nondiffusible, water-insoluble intracellular pigments, regardless of the presence of light. The colonial colours of strains JC2044 ${ }^{\mathrm{T}}$ and JC2045 were yellowish-red and red, respectively. Both strains produced a metallic green sheen on plates of MA, CSY-3 (Sawabe et al., 1998), medium B

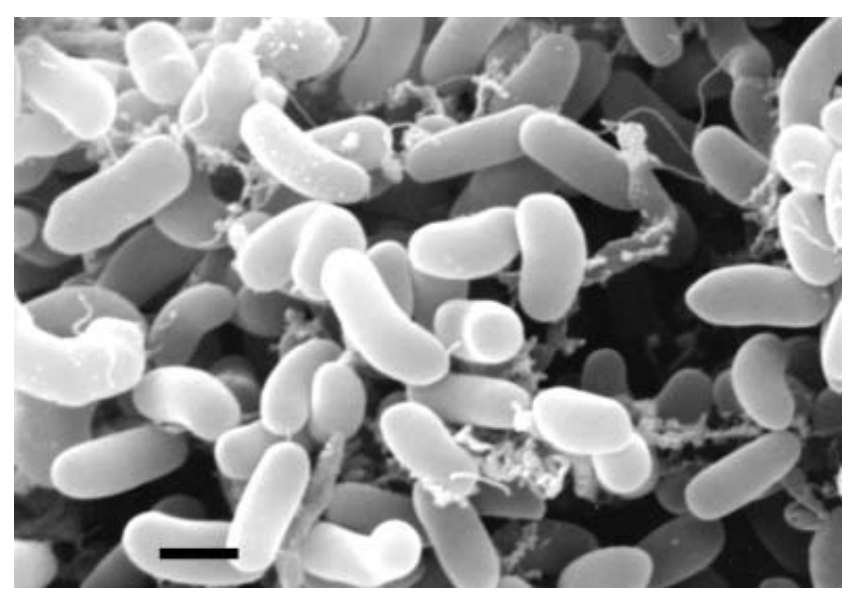

Fig. 2. Scanning electron micrograph of strain JC2044 ${ }^{\top}$. Cells were grown on MA at $30^{\circ} \mathrm{C}$ for 2 days. Bar, $1 \mu \mathrm{m}$. 
(Ivanova et al., 1996), yeast extract agar (YEA; Baumann et al., 1972) and YTSS agar (Gonzalez et al., 1997). However, colonies grown on basal medium (BM; Baumann et al., 1972) agar showed little pigmentation and no metallic sheen. When grown on MA at $30^{\circ} \mathrm{C}$, the strains showed translucent colonies at early stages of growth (12-18 h), then changed to a faint reddish hue $(24 \mathrm{~h})$ and finally became deep red with a metallic sheen (24-30 h). A lower extent of metallic sheen was produced at $35^{\circ} \mathrm{C}$ than at $15-30{ }^{\circ} \mathrm{C}$. When grown in liquid medium, the test strains produced abundant red pigment but no metallic sheen.

A distinctive feature of our isolates was their ability to produce a large amount of red pigment. The pigment showed characteristics similar to prodigiosin, as it is insoluble in water and has a red colour with a metallic green sheen. Prodigiosin has been reported to be deposited in the cell envelope and not released into the medium; in addition, in its amorphous state it has an appearance of red platelets with a green metallic sheen (Margalith, 1992), and a maximum absorption of 535-540 nm (Allen, 1967). Serratia marcescens is well-known as a producer of prodigiosin. The red cellular pigments of our isolates were extracted with absolute ethanol from freeze-dried biomass and analysed spectrophotometrically (Gauthier \& Breittmayer, 1992). The absorption spectra of crude extracts were determined in the range $200-800 \mathrm{~nm}$ using a spectrophotometer (Ultrospec 2000, Amersham Biosciences). The absorption spectra of pigments from our isolates were nearly identical to that of prodigiosin isolated from S. marcescens ATCC 27117, with a maximum peak at $540 \mathrm{~nm}$. However, the next largest peaks were slightly different in all spectra $(471-473 \mathrm{~nm}$ for S. marcescens, 495-499 $\mathrm{nm}$ for strain JC2044 ${ }^{\mathrm{T}}$ and $491-496 \mathrm{~nm}$ for strain JC2045).

To examine bacterial growth, the isolates were inoculated onto several bacteriological growth media. Abundant growth was observed on medium B and YTSS, and the best growth was observed on CSY-3, YEA and MA. The isolates grew weakly on $\mathrm{BM}, \mathrm{BM}$ with $0.01 \%$ yeast extract (Baumann et al., 1972) and the basal medium for H. chejuensis (Lee et al., 2001), and failed to grow on Luria-Bertani (supplemented with ASW), nutrient (supplemented with ASW), PYSE (Yumoto et al., 1998) and tryptic soy (supplemented with ASW) agar plates. After various media were evaluated, BM and BM with $0.01 \%$ yeast extract were chosen as the basal media for the carbon source utilization test.

The two getbol isolates showed little growth under anaerobic conditions produced by the GasPak system (BBL). The $\mathrm{pH}$ range for growth was $5-8$ and optimal growth was observed at $\mathrm{pH} 7$ in medium $\mathrm{B}$ broth. The test strains had an absolute requirement for $\mathrm{Na}^{+}$in the range $1-7 \%(\mathrm{w} / \mathrm{v}) \mathrm{NaCl}$, and the optimum concentration was $3-4 \%(\mathrm{w} / \mathrm{v})$ in medium $\mathrm{B}$ broth. The temperature range for growth was $15-45^{\circ} \mathrm{C}$ and the optimum temperature was $35^{\circ} \mathrm{C}$ on MA, YEA and CSY-3 agar plates and in medium B broth. Extended incubation (up to 1 month) was required at $15^{\circ} \mathrm{C}$.

Standard physiological and biochemical tests were performed as described previously (Baumann et al., 1972; Koneman et al., 1979; Smibert \& Krieg, 1994). Decarboxylation of amino acids (arginine, lysine and ornithine) was determined after 4 days, using decarboxylase medium base (Ewing et al., 1960) supplemented with $2 \cdot 5 \%(\mathrm{w} / \mathrm{v}) \mathrm{NaCl}$. Production of $\mathrm{H}_{2} \mathrm{~S}$ was detected in triple-sugar iron agar supplemented with $2.5 \%(\mathrm{w} / \mathrm{v}) \mathrm{NaCl}$ and fluorescein production was tested in fluorescence-denitrification medium supplemented with $2 \cdot 5 \%(\mathrm{w} / \mathrm{v}) \mathrm{NaCl}$. For determination of acetoin production, strains were grown in YEB broth with $1 \%$ glucose according to Baumann et al. (1972). After $72 \mathrm{~h}$ incubation, the Voges-Proskauer test was performed. Oxidation or fermentation of glucose was examined using marine oxidation-fermentation medium (Leifson, 1963). Hydrolyses of agar, alginic acid, casein, chitin, lecithin, starch and Tween 80 were tested using MA as the basal medium. Degradation of cellulose was tested on MA containing $0.5 \%$ CM-cellulose (Sigma) and the Congo red test (Skipper et al., 1985) was performed after 7 days at $35^{\circ} \mathrm{C}$. DNase test agar (Difco) supplemented with $50 \%$ ASW was used for the DNase assay. Accumulation of poly$\beta$-hydroxybutyrate was determined by staining nitrogenlimited cells (grown on BM agar containing $0 \cdot 1 \%$ D-glucose and $0.01 \%$ yeast extract) with Nile blue A, according to Ostle \& Holt (1982). Utilization of various organic substrates as sole carbon sources (at a concentration of $0 \cdot 1 \%, \mathrm{w} / \mathrm{v}$ ) was tested on synthetic solid BM and BM with $0.01 \%$ yeast extract (Difco) agar. Additional biochemical tests were performed using the API 20NE and API ZYM kits (bioMérieux). Strips were inoculated with a heavy bacterial suspension in ASW or AUX medium supplemented with $20 \%$ sea salt (Sigma). The results of biochemical and physiological tests are summarized in Table 1. Strains JC2044 ${ }^{\mathrm{T}}$ and JC2045 had almost-identical physiological and biochemical profiles. Only six traits were different between these strains, as indicated in Table 1.

\section{Chemotaxonomy}

Isoprenoid quinones were analysed by using HPLC, according to Minnikin et al. (1984) and Collins (1985). The predominant isoprenoid quinone of the test strains was ubiquinone-9 (Q-9). Fatty acid methyl esters were prepared from biomass that was scraped from MA after 5 days incubation at $30^{\circ} \mathrm{C}$ and analysed by GC, according to the instructions of the Microbial Identification system (MIDI). The profiles of cellular fatty acids are given in Table 2. Strains JC2044 ${ }^{\mathrm{T}}$ and JC2045 gave almost-identical patterns; the predominant fatty acids were saturated and monounsaturated.

DNA was prepared according to Wolff \& Gemmill (1997) and the $\mathrm{G}+\mathrm{C}$ content of the DNA was determined by HPLC of deoxyribonucleosides as described by Mesbah et al. (1989), using a Supelcosil LC-18-S reverse-phase 
Table 1. Physiological and biochemical features of strains JC2044 ${ }^{\top}$ and JC2045

+, Positive reaction; -, negative reaction; $\mathrm{W}$, weakly positive. Strains JC2044 ${ }^{\mathrm{T}}$ and JC2045 were positive in the tests for catalase, oxidase, arginine dihydrolysis, ornithine decarboxylation, hydrolysis of DNA, gelatin and lecithin, alkaline phosphatase, esterase (C4), esterase lipase (C8), leucine arylamidase, valine arylamidase and acid phosphatase. Weakly positive reactions were observed for cystine arylamidase and naphthol-AS-BI-phosphohydrolase. Both strains showed negative reactions in the tests for lysine decarboxylation, fluorescein, $\beta$-galactosidase, poly- $\beta$-hydroxybutyrate accumulation, urease, production of acetoin, $\mathrm{H}_{2} \mathrm{~S}$ and indole, hydrolysis of aesculin, agar, alginic acid, casein, cellulose, chitin, starch and Tween 80 , activities of trypsin, $\alpha$-chymotrypsin, $\alpha$-galactosidase, $\beta$-galactosidase, $\beta$-glucuronidase, $\beta$-glucosidase, $\alpha$-mannosidase and $\alpha$-fucosidase. Organic compounds utilized by both strains were as follows: D-fructose, D-glucose, D-ribose, D-trehalose, L-asparagine, L-tyrosine, malate, maltose, $\mathrm{N}$-acetylglucosamine and succinate. Adenine was weakly utilized. Organic compounds utilized by neither strain were as follows: acetamide, acetate, adipate, benzoate, caprate, citrate, D-cellobiose, D-galactose, D-mannitol, D-mannose, D-raffinose, D-salicin, D-sorbitol, D-xylose, ethanol, gluconate, glycerol, glycine, inositol, inulin, lactose, L-arabinose, L-ascorbate, L-cysteine, L-lysine, L-rhamnose, PEG, phenylacetate, propan-2-ol, sucrose and thiamin. Both strains were able to produce acid fermentatively from glucose.

\begin{tabular}{|lcc|}
\hline Characteristic & JC2044 $^{\text {T }}$ & JC2045 \\
\hline Nitrate reduction & $\mathrm{W}$ & + \\
API ZYM: & & \\
$\quad$ Lipase (C14) & - & + \\
$\alpha$-Glucosidase & + & $\mathrm{W}$ \\
$\quad$-Acetyl- $\beta$-glucosaminidase & - & + \\
Utilization of: & & + \\
L-Arginine & $\mathrm{W}$ & + \\
L-Ornithine & $\mathrm{W}$ & \\
\hline
\end{tabular}

Table 2. Cellular fatty acid composition (\%) of strains JC2044 ${ }^{\top}$ and JC2045

Values are percentages of total fatty acids. $\mathrm{Tr},<0 \cdot 5 \%$.

\begin{tabular}{|lcr|}
\hline Fatty acid & JC2044 $^{\mathbf{T}}$ & JC2045 \\
\hline $\mathrm{C}_{10: 0}$ & $2 \cdot 6 \pm 0 \cdot 1$ & $3 \cdot 1 \pm 0 \cdot 1$ \\
$\mathrm{C}_{10: 0} 3-\mathrm{OH}$ & $2 \cdot 1 \pm 0 \cdot 1$ & $3 \cdot 2 \pm 0 \cdot 1$ \\
$\mathrm{C}_{12: 0}$ & $\mathrm{Tr}$ & $1 \cdot 7 \pm 0 \cdot 5$ \\
$\mathrm{C}_{12: 1} 3-\mathrm{OH}$ & $\mathrm{Tr}$ & $0 \cdot 8 \pm 0 \cdot 0$ \\
$\mathrm{C}_{12: 0} 3-\mathrm{OH}$ & $5 \cdot 1 \pm 0 \cdot 4$ & $5 \cdot 5 \pm 0 \cdot 2$ \\
$\mathrm{C}_{14: 0}$ & $6 \cdot 0 \pm 0 \cdot 1$ & $5 \cdot 4 \pm 0 \cdot 5$ \\
$\mathrm{C}_{16: 0}$ & $31 \cdot 9 \pm 0 \cdot 9$ & $29 \cdot 5 \pm 1 \cdot 0$ \\
$\mathrm{C}_{16: 1} \omega 7 c$ & $37 \cdot 1 \pm 0 \cdot 1$ & $36 \cdot 1 \pm 1 \cdot 5$ \\
$\mathrm{C}_{18: 1} \omega 7 c$ & $14 \cdot 5 \pm 0 \cdot 5$ & $13 \cdot 2 \pm 0 \cdot 6$ \\
$\mathrm{C}_{18: 0}$ & $0 \cdot 7 \pm 0 \cdot 2$ & $0 \cdot 5 \pm 0 \cdot 1$ \\
\hline
\end{tabular}

column (Supelco). The DNA G+C contents of strains JC2044 ${ }^{\mathrm{T}}$ and JC2045 were 42 and $40 \mathrm{~mol} \%$, respectively.

\section{Taxonomic conclusions}

Very low $16 \mathrm{~S}$ rDNA similarity values $(<92 \%)$ and the formation of a distinctive phyletic lineage clearly indicate that the two getbol isolates can be assigned to a novel genus in the $\gamma$-Proteobacteria. In addition, a number of phenotypic characters can be used to separate our isolates from their phylogenetic neighbours, the genera Hahella, Microbulbifer and Marinobacter (Table 3). On the basis of the polyphasic evidence presented in this study, it is proposed that the two getbol isolates should be classified in a novel genus and species as Zooshikella ganghwensis gen. nov., sp. nov.

\section{Description of Zooshikella gen. nov.}

Zooshikella (Zoo.shik.el'la. N.L. fem. n. Zooshikella named after Zoo Shik Lee, a Korean pioneer in food microbiology).

Gram-negative, aerobic, chemo-organotrophic, halophilic bacteria. Oxidase- and catalase-positive. Cells are rodshaped, slightly curved and motile by a single polar flagellum. $\mathrm{NaCl}$ is required $(1-7 \%, \mathrm{w} / \mathrm{v})$ for growth. Major isoprenoid quinone is Q-9. Predominant cellular fatty acids are saturated and monounsaturated straightchain fatty acids. DNA G+C content is $40-42 \mathrm{~mol} \%$. Phylogenetically, this genus is affiliated to the $\gamma$ Proteobacteria. The type species is Zooshikella ganghwensis.

\section{Description of Zooshikella ganghwensis sp. nov.}

Zooshikella ganghwensis (gang.hwen'sis. N.L. fem. adj. ganghwensis named after Ganghwa Island in Korea, the geographical origin of the type strain of the species).

In addition to the characteristics that define the genus, the species has the characteristics described below. Optimal growth is observed at $35^{\circ} \mathrm{C}, \mathrm{pH} 7$ and 3-4\% (w/v) $\mathrm{NaCl}$. Grows on MA, CSY-3, medium B, YEA and YTSS agar as circular, convex, entire, glistening, opaque and viscid colonies that are yellowish-red or red, approximately $1 \mathrm{~mm}$ in diameter after $36 \mathrm{~h}$ on $\mathrm{MA}$ at $30^{\circ} \mathrm{C}$ and reach the maximum diameter of $4-5 \mathrm{~mm}$ after 7 days. Cells are $0 \cdot 7-0.9 \mu \mathrm{m}$ in width and $1 \cdot 5-2.5 \mu \mathrm{m}$ in length. Detailed physiological and biochemical characteristics are given in Table 1. Large amounts of red pigment (maximum absorption at $540 \mathrm{~nm}$ ) with a metallic green sheen are produced on agar medium. Major fatty acids are $\mathrm{C}_{16: 0}$, $\mathrm{C}_{16: 1} \omega 7 c$ and $\mathrm{C}_{18: 1} \omega 7 c$. DNA $\mathrm{G}+\mathrm{C}$ content is 40-42 mol\%.

The type strain, JC2044 ${ }^{\mathrm{T}}\left(=\mathrm{IMSNU} \quad 14003^{\mathrm{T}}=\mathrm{KCTC}\right.$ $12044^{\mathrm{T}}=$ DSM $15267^{\mathrm{T}}$ ), was isolated from the sediment of getbol, the Korean tidal flat. 
Table 3. Major characteristics that differentiate strains JC2044 ${ }^{\top}$ and JC2045 from other phylogenetically related bacteria

Taxa: 1, strains JC2044 ${ }^{\mathrm{T}}$ and JC2045; 2, Hahella chejuensis; 3, Microbulbifer hydrolyticus; 4, Marinobacter aquaeolei; 5, Marinobacter hydrocarbonoclasticus. Data are from this and earlier studies (Gauthier et al., 1992; González et al., 1997; Nguyen et al., 1999; Lee et al., 2001). ND, Not determined.

\begin{tabular}{|c|c|c|c|c|c|}
\hline Characteristic & 1 & 2 & 3 & 4 & 5 \\
\hline Relation to oxygen & Aerobe & Facultative aerobe & Aerobe & Aerobe & Aerobe \\
\hline $\mathrm{pH}$ range for growth & $5-8$ & $6-10$ & $6 \cdot 5-8 \cdot 5$ & $5-10$ & $6-9 \cdot 5$ \\
\hline $\mathrm{Na}^{+}$requirement & $1-7 \%$ & $1-8 \%$ & $0 \cdot 1-0 \cdot 5 \mathrm{M}$ & $0-3 \cdot 4 \mathrm{M}$ & $0 \cdot 6-1.5 \mathrm{M}$ \\
\hline Arginine dihydrolase & + & - & $\mathrm{ND}$ & + & - \\
\hline Nitrate reduction & + & + & - & + & + \\
\hline Acid production from glucose & + & + & - & - & - \\
\hline Aesculin hydrolysis & - & + & $\mathrm{ND}$ & + & - \\
\hline Urease & - & - & ND & + & - \\
\hline DNase & + & ND & ND & ND & - \\
\hline Gelatin hydrolysis & + & + & + & + & - \\
\hline Acetate & - & ND & + & + & + \\
\hline Citrate & - & - & - & + & + \\
\hline D-Cellobiose & - & + & + & - & ND \\
\hline D-Fructose & + & + & - & - & ND \\
\hline D-Glucose & + & + & + & - & $\mathrm{ND}$ \\
\hline D-Mannitol & - & + & $\mathrm{ND}$ & - & $\mathrm{ND}$ \\
\hline D-Mannose & - & + & - & - & $\mathrm{ND}$ \\
\hline D-Ribose & + & - & ND & ND & - \\
\hline D-Sorbitol & - & + & ND & ND & - \\
\hline D-Xylose & - & - & + & ND & ND \\
\hline Glycerol & - & + & - & - & ND \\
\hline Sucrose & - & + & - & - & ND \\
\hline Thiamin & - & ND & + & ND & $\mathrm{ND}$ \\
\hline DNA G $+C$ content $(\mathrm{mol} \%)$ & $40-42$ & 55 & 58 & 56 & 53 \\
\hline Major fatty acids & $\begin{array}{c}\mathrm{C}_{16: 0}, \mathrm{C}_{16: 1} \omega 7 c \\
\mathrm{C}_{18: 1} \omega 7 c\end{array}$ & $\begin{array}{c}\mathrm{C}_{12: 0} 3-\mathrm{OH}, \mathrm{C}_{16: 0} \\
\mathrm{C}_{16: 1} \omega 9 c, \mathrm{C}_{18: 0}\end{array}$ & $\begin{array}{l}\text { i- } C_{15: 0} \\
\text { i- } C_{17: 1} \omega 9 c\end{array}$ & $\begin{array}{c}\mathrm{C}_{16: 0}, \mathrm{C}_{16: 1} \omega 9 c \\
\mathrm{C}_{18: 1} \omega 9 c\end{array}$ & $\begin{array}{c}\mathrm{C}_{16: 0} \\
\mathrm{C}_{18: 1} \omega 9 c\end{array}$ \\
\hline
\end{tabular}

\section{Acknowledgements}

We are grateful to J. P. Euzéby for help with nomenclature. This work was supported by the Korea Research Foundation (project no. KRF2001-041-D00207).

\section{References}

Allen, E. G. (1967). Conditions of the colour change of prodigiosin. Nature 216, 929-931.

Baumann, L., Baumann, P., Mandel, M. \& Allen, R. D. (1972). Taxonomy of aerobic marine eubacteria. J Bacteriol 110, 402-429.
Chun, J. \& Goodfellow, M. (1995). A phylogenetic analysis of the genus Nocardia with $16 \mathrm{~S}$ rRNA gene sequences. Int J Syst Bacteriol 45, 240-245.

Chun, J., Seong, C.-N., Bae, K. S., Lee, K.-J., Kang, S.-O., Goodfellow, M. \& Hah, Y. C. (1998). Nocardia flavorosea sp. nov. Int J Syst Bacteriol 48, 901-905.

Chun, J., Bae, K. S., Moon, E. Y., Jung, S.-O., Lee, H. K. \& Kim, S.-J. (2000). Nocardiopsis kunsanensis sp. nov., a moderately halophilic actinomycete isolated from a saltern. Int J Syst Evol Microbiol 50, 1909-1913.

Collins, M. D. (1985). Analysis of isoprenoid quinones. Methods Microbiol 18, 329-366. 
Ewing, W. H., Davis, B. R. \& Edwards, P. R. (1960). The decarboxylase reaction of Enterobacteriaceae and their value in taxonomy. Publ Health Lab 18, 77-83.

Felsenstein, J. (1985). Confidence limits on phylogenies: an approach using the bootstrap. Evolution 39, 783-791.

Felsenstein, J. (1993). PHYLIP (phylogeny inference package), version 3.5.1. Department of Genetics, University of Washington, Seattle, USA.

Fitch, W. M. (1971). Toward defining the course of evolution: minimum change for a specific tree topology. Syst Zool 20, 406-416.

Fitch, W. M. \& Margoliash, E. (1967). Construction of phylogenetic trees. Science 155, 279-284.

Gauthier, M. J. \& Breittmayer, V. A. (1992). The genera Alteromonas and Marinomonas. In The Prokaryotes. Edited by A. Balows, H. G. Trüper, M. Dworkin, W. Harder \& K.-H. Schleifer. New York: Springer-Verlag.

Gauthier, M. J., Lafay, B., Christen, R., Fernandez, L., Acquaviva, M., Bonin, P. \& Bertrand, J.-C. (1992). Marinobacter hydrocarbonoclasticus gen. nov., sp. nov., a new, extremely halotolerant, hydrocarbondegrading marine bacterium. Int J Syst Bacteriol 42, 568-576.

González, J. M., Mayer, F., Moran, M. A., Hodson, R. E. \& Whitman, W. B. (1997). Microbulbifer hydrolyticus gen. nov., sp. nov., and Marinobacterium georgiense gen. nov., sp. nov., two marine bacteria from a lignin-rich pulp mill waste enrichment community. Int J Syst Bacteriol 47, 369-376.

Ivanova, E. P., Kiprianova, E. A., Mikhailov, V. V., Levanova, G. F., Garagulya, A. D., Gorshkova, N. M., Yumoto, N. \& Yoshikawa, S. (1996). Characterization and identification of marine Alteromonas nigrifaciens strain and emendation of the description. Int J Syst Bacteriol 46, 223-228.

Jukes, T. H. \& Cantor, C. R. (1969). Evolution of protein molecules. In Mammalian Protein Metabolism, pp. 21-132. Edited by H. N. Munro. New York: Academic Press.

Koneman, E. W., Allen, S. D., Dowell, V. R. \& Sommers, H. M. (1979). Color Atlas and Textbook of Diagnostic Microbiology. Philadelphia, PA: J. B. Lippincott.

Korea Ocean Research \& Development Institute (1998). Tidal flat studies for conservation and sustainable use. Seoul, Korea: a project of the Korea Ocean Research \& Development Institute (KORDI), available at http://www.kordi.re.kr/eng/kordi/research98//ih38.asp.

Lee, H. K., Chun, J., Moon, E. Y., Ko, S.-H., Lee, D.-S., Lee, H. S. \& Bae, K. S. (2001). Hahella chejuensis gen. nov., sp. nov., an extracellular-polysaccharide-producing marine bacterium. Int J Syst Evol Microbiol 51, 661-666.

Leifson, E. (1963). Determination of carbohydrate metabolism of marine bacteria. J Bacteriol 85, 1183-1184.
Lyman, J. \& Fleming, R. H. (1940). Composition of sea water. J Mar Res 3, 134-146.

Margalith, P. Z. (1992). Pigment Microbiology. London: Chapman \& Hall.

Mesbah, M., Premachandran, U. \& Whitman, W. B. (1989). Precise measurement of the $\mathrm{G}+\mathrm{C}$ content of deoxyribonucleic acid by highperformance liquid chromatography. Int J Syst Bacteriol 39, 159-167.

Minnikin, D. E., O'Donnell, A. G., Goodfellow, M., Alderson, G., Athayle, M., Schaal, A. \& Parlett, J. H. (1984). An integrated procedure for the extraction of isoprenoid quinones and polar lipids. J Microbiol Methods 2, 233-241.

Nguyen, B. H., Denner, E. B. M., Dang, T. C. H., Wanner, G. \& StanLotter, H. (1999). Marinobacter aquaeolei sp. nov., a halophilic bacterium isolated from a Vietnamese oil-producing well. Int J Syst Bacteriol 49, 367-375.

Ostle, A. G. \& Holt, J. G. (1982). Nile blue A as a fluorescent stain for poly- $\beta$-hydroxybutyrate. Appl Environ Microbiol 44, 238-241.

Saitou, N. \& Nei, M. (1987). The neighbor-joining method: a new method for reconstructing phylogenetic trees. Mol Biol Evol 4, 406-425.

Sawabe, T., Makino, H., Tatsumi, M., Nakano, K., Tajima, K., Iqbal, M. M., Yumoto, I., Ezura, Y. \& Christen, R. (1998). Pseudoalteromonas bacteriolytica sp. nov., a marine bacterium that is the causative agent of red spot disease of Laminaria japonica. Int J Syst Bacteriol 48, 769-774.

Skipper, N., Sutherland, M., Davies, R. W., Kilburn, D., Miller, R. C., Jr, Warren, A. \& Wong, W.-K. R. (1985). Secretion of a bacterial cellulase by yeast. Science 230, 958-960.

Smibert, R. M. \& Krieg, N. R. (1994). Phenotypic characterization. In Methods for General and Molecular Bacteriology, pp. 607-654. Edited by P. Gerhardt, R. G. E. Murray, W. A. Wood \& N. R. Krieg. Washington, DC: American Society for Microbiology.

Swofford, D. L. (1998). Phylogenetic analysis using parsimony (PAUP), version 4. Sunderland, MA: Sinauer Associates.

Wayne, L. G., Brenner, D. J., Colwell, R. R. \& 9 other authors (1987). International Committee on Systematic Bacteriology. Report of the ad hoc committee on reconciliation of approaches to bacterial systematics. Int J Syst Bacteriol 37, 463-464.

Wolff, R. \& Gemmill, R. (1997). Purifying and analyzing genomic DNA. In Genome Analysis: A Laboratory Manual, vol. 1, pp. 1-82. Edited by E. D. Green, B. Birren, S. Klapholz, R. M. Myers \& P. Hieter. Cold Spring Harbor, NY: Cold Spring Harbor Laboratory Press.

Yumoto, I., Kawasaki, K., Iwata, H., Matsuyama, H. \& Okuyama, H. (1998). Assignment of Vibrio sp. strain ABE-1 to Colwellia maris sp. nov., a new psychrophilic bacterium. Int J Syst Bacteriol 48, $1357-1362$. 